\title{
Satellite altimetry reveals spatial patterns of variations in the Baltic Sea wave climate
}

\author{
Nadezhda Kudryavtseva ${ }^{1}$ and Tarmo Soomere ${ }^{1,2}$ \\ ${ }^{1}$ Wave Engineering Laboratory, Department of Cybernetics, School of Science, Tallinn University of \\ Technology, Akadeemia tee 21, Tallinn, 12 618, Estonia \\ ${ }^{2}$ Estonian Academy of Sciences, Kohtu 6, Tallinn, 10 130, Estonia \\ Correspondence to: Tarmo Soomere (soomere@cs.ioc.ee)
}

Received: 6 December 2016 - Discussion started: 15 December 2016

Revised: 7 April 2017 - Accepted: 23 April 2017 - Published: 8 August 2017

\begin{abstract}
The main properties of the climate of waves in the seasonally ice-covered Baltic Sea and its decadal changes since 1990 are estimated from satellite altimetry data. The data set of significant wave heights (SWHs) from all existing nine satellites, cleaned and cross-validated against in situ measurements, shows overall a very consistent picture. A comparison with visual observations shows a good correspondence with correlation coefficients of $0.6-0.8$. The annual mean SWH reveals a tentative increase of $0.005 \mathrm{~m} \mathrm{yr}^{-1}$, but higher quantiles behave in a cyclic manner with a timescale of 10-15 years. Changes in the basin-wide average SWH have a strong meridional pattern: an increase in the central and western parts of the sea and a decrease in the east. This pattern is likely caused by a rotation of wind directions rather than by an increase in the wind speed.
\end{abstract}

\section{Introduction}

The wave climate of relatively small semi-sheltered and seasonally ice-covered water bodies serves as a convenient indicator of changes in the atmospheric circulation and the related response of the water masses (Anderson et al., 2015). The associated changes in the wave fields are to a large extent controlled by the interplay of the geometry of the water body, changing winds, and the overall reaction of the water masses. For instance, a reduction in the ice cover may strongly affect the wave loads (Tuomi et al., 2011; Ruest et al., 2016) and even small variations in wind properties may lead to marked changes in the wave fields. The analysis of wave properties makes it possible to reveal otherwise hidden changes in the forcing such as regime shifts (Soomere et al., 2015) and to highlight an unusual reaction of the impacted environment, both direct (e.g., through an increase in the severity of wave conditions - Wahl and Plant, 2015) and indirect (e.g., owing to a reduction in the ice cover - Orviku et al., 2003 - or a change in the wave direction - Ashton et al., 2001).

The limited size of such water bodies leads to large spatiotemporal variations in the wave properties. Thus, all sources of information about wave fields adequately reflect only wave conditions in the vicinity of the device or observation site. This feature is particularly significant in the Baltic Sea and similar water bodies that host extensive spatial variations in their wave climate (Soomere and Räämet, 2011, 2014). The related biases and uncertainties are generally recognized for several kinds of data sources such as visual observations from ships (Gulev and Grigorieva, 2006) or coastal locations (Hünicke et al., 2015) but are often overlooked in the analysis of acoustic Doppler current profiler (ADCP) or Waverider buoy data (Suursaar, 2015). Moreover, wave measurement devices are often removed well before the ice season (Tuomi et al., 2011).

Wave modeling provides a feasible option to complete the description of the wave climate and its changes. The major limitation is the wind quality. Even though reconstructed wind fields are adequate for the Baltic Sea, replication of the wave climate is still a major challenge for this basin (Tuomi et al., 2011, 2014; Hünicke et al., 2015). An intrinsic reason is the variability of ice cover extension from 12.5 to $100 \%$ of the sea surface (Leppäranta and Myrberg, 2009). Various decadal reconstructions show qualitatively similar patterns but reveal significant quantitative mismatches between dif- 
ferent model outputs (Nikolkina et al., 2014) and between modeled and measured wave data.

Here, we systematically employ the information about wave properties derived from satellite altimetry to quantify the wave climate of the Baltic Sea in terms of significant wave height $(\mathrm{SWH})$. The relevant observations span today $>20$ years and thus provide a valuable source for understanding the course and possible reasons for regional climate changes. Satellite altimetry provides homogeneous and continuous (along a certain line) data about the sea state over large areas in the open ocean (Hemer et al., 2010; Izaguirre et al., 2011; Young et al., 2011). Several recent studies have addressed the options for its use in the Arctic Ocean (Liu et al., 2016; Stopa et al., 2016). However, it fails to provide information about low waves, is not applicable in the vicinity of land (Høyer and Nielsen, 2006), and is problematic for sea areas with high ice concentrations. It is thus not surprising that it has been only scarcely used to validate model results in the Baltic Sea (Cieślikiewicz et al., 2008; Tuomi et al., 2011). With certain precautions in place, it has shown good results for basins such as the Mediterranean Sea (Cavaleri and Sclavo, 2006; Galanis et al., 2012), a nearshore region of the Indian Ocean (Hareef Baba Shaeb et al., 2015; Patra and Bhaskaran, 2016), and for a range of regional seas such as the China Sea (Kong et al., 2016), the Arabian Sea (Hithin et al., 2015), the Chukchi Sea (Francis et al., 2011), or the German Bight (Passaro et al., 2015).

\section{Data and methods}

We employ the Radar Altimeter Database System (RADS) database (http://rads.tudelft.nl/rads/rads.shtml) (Scharroo et al., 2013). It provides data from nine satellites from 1985 to 2015 (Table 1) that are uniformly reduced for multiple missions. Doing so diminishes the bias between data from different satellites and makes it possible to examine longterm changes in the wave climate. As several phenomena may substantially affect the quality of satellite altimetry, the consistency of the data has to be carefully checked. The relevant procedures, details about the missions and their temporal coverage, and the validation of the data against the records of Waverider buoys and echosounder measurements are presented in Kudryavtseva and Soomere (2016). Here, we provide only major aspects that are relevant for the subsequent analysis.

Different satellites have various densities of measurements. For example, SARAL and CryoSat-2 data fairly densely cover the entire Baltic Sea within each month (Fig. 1a), whereas the Poseidon data, for example, have very sparse coverage. We used flags provided by each mission (e.g., bad data because of rain or the presence of sea ice) as well as flags 7 and 11-13 in the RADS database that indicated possible large errors in range, backscatter coefficient, and SWH. The data with a backscatter coefficient $>13.5 \mathrm{cdb}$
Table 1. Description of satellite missions used in the paper. As the number of observations made by the TOPEX/Poseidon mission was small, it was not possible to adequately validate these data (Kudryavtseva and Soomere 2016); the relevant data set is not used in the analysis presented in this paper.

\begin{tabular}{llrr}
\hline Satellite & $\begin{array}{l}\text { Period of } \\
\text { observations }\end{array}$ & $\begin{array}{r}\text { Accuracy } \\
(m)\end{array}$ & $\begin{array}{r}\text { Repeat cycle } \\
(d)\end{array}$ \\
\hline GEOSAT & $1985-1989$ & 0.10 & 17.05 \\
& $2000-2008$ & 0.10 & 17.05 \\
ERS-1 & $1991-1996$ & 0.05 & $3 / 35 / 168$ \\
TOPEX & $1992-2005$ & 0.02 & 9.9156 \\
Poseidon & $1992-2002$ & 0.02 & 9.9156 \\
ERS-2 & $1995-2004$ & 0.03 & 35 \\
ENVISAT & $2002-2012$ & 0.03 & 35 \\
Jason-1 & $2002-2013$ & 0.02 & 9.9156 \\
Jason-2 & $2008-2015$ & 0.02 & 9.9156 \\
CryoSat-2 & $2010-2015$ & 0.05 & 369 \\
SARAL/AltiKa & $2013-2015$ & 0.02 & 35 \\
\hline
\end{tabular}

(generally corresponding to wind speeds of $<2.5 \mathrm{~m} \mathrm{~s}^{-1}$ ) and large errors $(>0.5 \mathrm{~m}$, which is about half of the typical Baltic Sea wave height (Tuomi et al., 2011)) in SWH normalized standard deviation (SD) were excluded. The attitude flag 1 was applied to the GEOSAT data (Sandwell and McAdoo, 1988) and the zero values of SWH recorded by Jason-1 and ERS-1 were removed as likely being erroneous. The GEOSAT phase-1 data could not be validated with the available buoy data and were excluded from the further analysis.

Possible biases of SWH for different missions were removed using cross matching with in situ data and between satellites. The match of altimetry-derived and measured SWH is the best offshore in the Baltic proper due to a large number of data points. When compared with the in situ data the cross matched pairs showed bigger scatter for the Waverider buoys and echo sounders closer to the shore. For the in situ measurement sites located less than $0.2^{\circ}$ from the coast, the standard deviation of cross matches showed an increase of $14 \%$. However, the bigger scatter next to the shore does not affect the results of this study on condition that the data reflecting sea areas separated $<0.2^{\circ}$ from the coast were excluded from the analysis. The largest amount of matching altimetry and in situ data exists for Jason-1 (Fig. 1b). These sets reveal fairly small scatter, no systematic shift, and a fairly small (around $4 \%$ ) difference. TOPEX tends to overestimate the SWH by about $0.17 \mathrm{~m}$, whereas ENVISAT, ERS1 , and GEOSAT phase 2 tend to underestimate the SWH by $0.15-0.23 \mathrm{~cm}$. The bias is less than $0.06 \mathrm{~m}$ for all other satellites. The bias between the SWH from different missions is consistent with the bias derived from comparison with the in situ data. For example, for CryoSat- 2 and Jason1 , it is $0.04 \pm 0.06 \mathrm{~m}$, and for ENVISAT and Jason- 1 it is $-0.19 \pm 0.03 \mathrm{~m}$. 

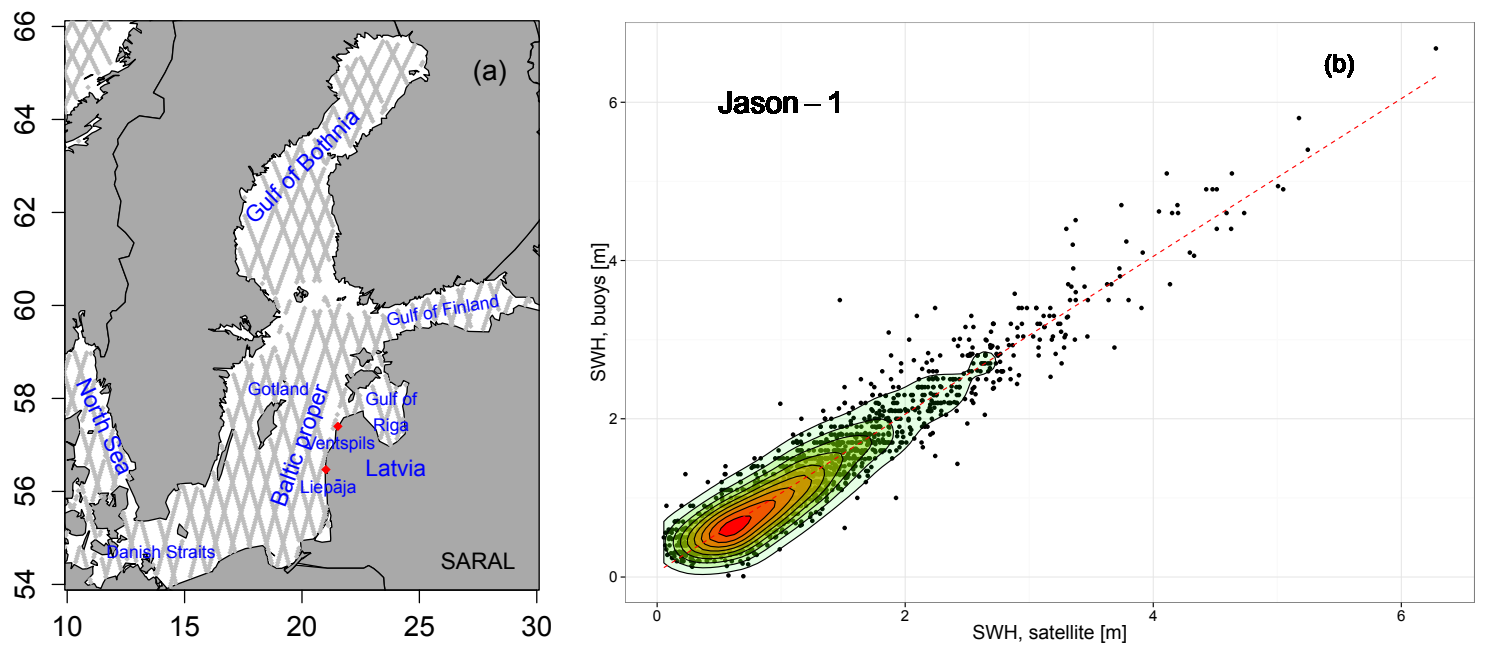

Figure 1. Validation of satellite altimetry data: (a) an example of the monthly visits of SARAL to the Baltic Sea region; (b) a comparison of SWH derived using Jason-1 and in situ data. Adapted from Kudryavtseva and Soomere (2016).

The data for the 1990s require additional handling. TOPEX had a switch in electronics in February 1999, which resulted in a shift in the time series. The TOPEX observations since February 1999 showed no bias with Jason-1. However, there is a bias of $0.37 \mathrm{~m}$ between ERS- 1 and TOPEX for 1991-1996. The buoy data revealed that the ERS-1 underestimated the SWH by $0.18 \mathrm{~m}$ and TOPEX overestimated it by $0.17 \mathrm{~m}$ in $1991-1996$. Several satellites have significant drift in their SWH time series. The highest differences are between SARAL and Jason-2.

Even though part of the drift can be related to different frequencies of observations, some of the altimetry data sets eventually are not homogeneous in time. The absolute drift is reasonable $(0.13 \mathrm{~m}$ for ENVISAT/Jason- $1,0.08 \mathrm{~m}$ for SARAL/Jason-2, and $0.05 \mathrm{~m}$ for ERS-1/TOPEX) and does not affect the conclusions of this study. The overall corrections, based on the relevant linear regression analysis, are applied to the data: ERS-1 increased by $0.18 \mathrm{~m}$, ENVISAT increased by $0.19 \mathrm{~m}$ and divided by 1.06 , GEOSAT increased by $0.23 \mathrm{~m}$, Jason- 2 data divided by 1.009 , and TOPEX before February 1999 decreased by $0.17 \mathrm{~m}$ and after that divided by 1.014 (Kudryavtseva and Soomere, 2016).

Consistently with earlier analysis, a clear increase in the scattering of buoy-satellite cross matches was found for centroids of the satellite snapshots separated $<0.2^{\circ}$ from the land. Such snapshots were excluded.

Large parts of the Baltic Sea are covered with ice each winter. Widespread variations in the extent of ice cover are an intrinsic and deeply nontrivial question in studies of the wave climate of partially ice-covered sea areas. The presence of extensive ice cover may render the basic properties such as average wave height almost meaningless (Tuomi et al., 2011). For cross matching the wave height data with the ice concentration measurements we used the OSI-409-a dataset, taken from EUMETSAT OSI SAF (Ocean and Sea Ice Satellite Application Facility) Global Sea Ice Concentration Reprocessing data (EUMETSAT Ocean and Sea Ice Satellite Application Facility, 2015). We found that the presence of sea ice starts to affect the SWH values at concentrations as low as $10 \%$, and the wave heights are somewhat lower when ice concentration exceeds $30 \%$. The ice flag in the RADS data indicates an ice concentration $>50 \%$. This threshold is appropriate for the Baltic Sea. Still, lowering it to the level of $>30 \%$ would result in the additional exclusion of only $0.1 \%$ of the altimetry data (Kudryavtseva and Soomere, 2016).

\section{Results}

\subsection{Observed changes and trends}

The average SWH of the Baltic Sea in 1991-2015 is in the range of $0.44-1.94 \mathrm{~m}$ (Fig. 2). As roughly one-third of calmer conditions is excluded from the analysis, the resulting values are clearly overestimated. For example, in a location in the southern Baltic proper where Soomere and Räämet (2014) (who underestimate SWH by about $15 \%$ ) report an average SWH of $\sim 0.7 \mathrm{~m}$, the altimeter SWH is $1.294 \pm 0.002 \mathrm{~m}$. The average SWH exceeds the levels simulated in Soomere and Räämet (2014) by 60-90\% and the levels reconstructed by Tuomi et al. (2011) by about $30 \%$. The satellite-derived dataset, however, is expected to reflect spatial patterns and temporal changes in the wave heights and the proportion of severe wave conditions adequately.

Consistently with Tuomi et al. (2011), Soomere and Räämet (2014), and Hünicke et al. (2015), the highest waves are found in the eastern and southeastern Baltic proper, whereas the Gulf of Finland, Gulf of Riga, and the (south)western parts of the sea host much lower wave activity. The match of the frequency of satellite-derived and mea- 


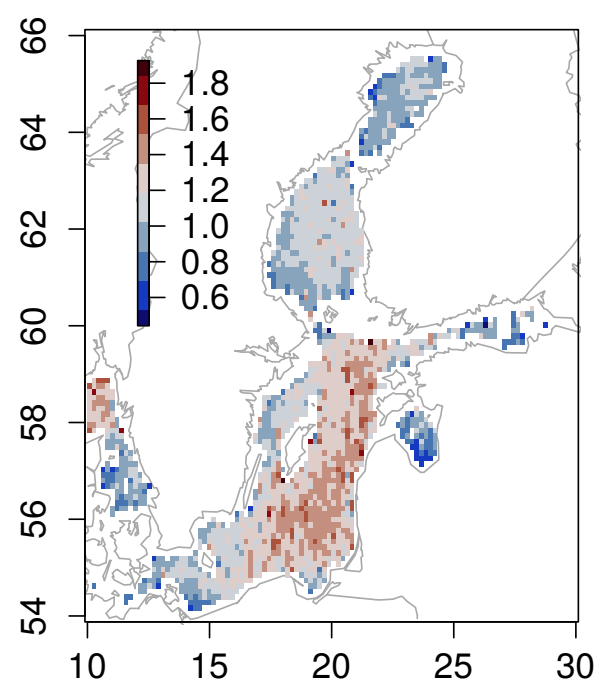

Figure 2. Average significant wave height ( $\mathrm{m}$; color scale) in the Baltic Sea in 1993-2015 from satellite altimetry. The approximate pixel size is $0.2 \times 0.1^{\circ}(100 \times 100$ pixel grid $)$.

sured very rough seas is fairly good. Wave conditions with an $\mathrm{SWH} \geq 4 \mathrm{~m}$ form $0.6 \%$ of satellite snapshots in the entire sea, whereas this proportion varies from 0.42 to $1.4 \%$ in various locations (Soomere, 2016). Extremely rough seas $(\mathrm{SWH} \geq 7 \mathrm{~m})$ occur twice $(0.001 \%)$ in the satellite data: $7.3 \mathrm{~m}$ on 31 January 1998 in the southern Baltic proper and $7.4 \mathrm{~m}$ on 1 November 2001 in the northern Baltic proper. Such wave conditions have been recorded less than 10 times in the entire Baltic Sea since 1978 (Soomere, 2016).

The major qualitative features of the basin-wide average SWH in 1991-2007 (Fig. 3), such as high wave activity in 1992 or 2007 and low wave activity in 1991, 1996, and 2006, match similar features of simulations based on geostrophic winds and ice-free sea (Soomere and Räämet, 2014) and the results of visual wave observations (Soomere et al., 2015). However, there is a mismatch between the course of interannual variations and, more importantly, between the signs of trends in the average SWH established in the studies mentioned and those obtained in our analysis. Earlier analysis indicates an increase in the SWH and also in upper quantiles of the wave height in the open part of the Baltic Sea (Hünicke et al., 2015). These results are not confirmed by direct measurements (Broman et al., 2006; Soomere et al., 2012) and do not become visible in the outcome of fetch-based models (Suursaar, 2015). Also, the analysis of Soomere and Räämet (2014) show no significant trend in mean wave heights integrated over the entire Baltic Sea. Instead, the Baltic Sea wave fields exhibit extensive decadalscale variations that are out of phase in different subbasins. In contrast, our study shows a tentative positive trend. It is worth noting, however, that the modeling results in partially ice-covered seas are affected by how the ice is treated in the modeling process (Tuomi et al., 2011; Ruest et al., 2016) and different runs often exhibit large discrepancy in the results (Nikolkina et al., 2014).

The number of single altimetry observations per year is $<12000$ in 1991-1992, in the range of 20000-31500 in 1993-2001, and $>30000$ since 2002 (Fig. 3d). This suggests that the data until 1992 are only conditionally usable to highlight long-term changes in the wave properties. For this reason, we only consider trends in the wave activity since 1993. The linear trend for 1993-2015 (based on 683707 measurements) is $0.005 \mathrm{~m} \mathrm{yr}^{-1}$ at a $98 \%$ significance level. It is consistent with a similar pattern in the 90th and 99th percentiles for the North Atlantic (Bertin et al., 2013) but is clearly weaker than analogous trends extracted from numerical simulations using modeled wind fields (Hünicke et al., 2015) and disagrees with wave properties reconstructed using geostrophic winds (Soomere and Räämet, 2014). Consistently with Bertin et al. (2013), this trend is superimposed by marked interannual variability. As most of the increase is caused by variations in the 1990s, it does not necessarily mirror the long-term changes adequately. A similar trend in 2000-2015 is $0.002 \mathrm{~m} \mathrm{yr}^{-1}$. A large value of the relevant $p$ value ( $p=0.5$ ) signals that no significant changes in the basin-wide average SWH have occurred during the last 15 years.

\subsection{Testing the presence of trends}

Following Wang and Swail (2001), an additional test to check the reliability of the whole-basin long-term trend in wave heights of $0.005 \mathrm{~m} \mathrm{yr}^{-1}$ was performed using the MannKendall test since the least square fitting of a regression line is sensitive to gross errors and non-normality of the parent distribution (Sen, 1968). The Mann-Kendall test (Mann, 1945; Kendall, 1955) is a nonparametric test for nonrandomness of the data. The method is sensitive to the autocorrelation in the data (von Storch and Navarra, 1995). Therefore, a bootstrapping of the data was performed ("boot" $\mathrm{R}$ package, version 1.3.17) with 5000 runs. For each run, a MannKendall test was applied ("Kendall” R package, version 2.2), and the results of the trial were averaged.

The average wave heights showed a significant autocorrelation of 0.4 with a lag of 1 and 2 years, whereas the higher percentiles showed no evidence of the serial correlation. The Mann-Kendall test disproved the presence of a trend in the basin-wide wave height annual means, 90th percentile, and 99th percentile (tau statistics is $0.01,0.03$, and 0.005 , respectively). This conjecture is consistent with the results of WAM (WAve Model) simulations using geostrophic winds (Soomere and Räämet, 2014). We also checked the basinwide annual means, 90th percentile, and 99th percentile for each separate season and also did not find any significant trends with the bootstrapped Mann-Kendall test.

The scarcity of changes in the basin-wide SWH and 90th and 99th percentiles agrees with wave properties reconstructed using geostrophic winds (Soomere and Räämet, 

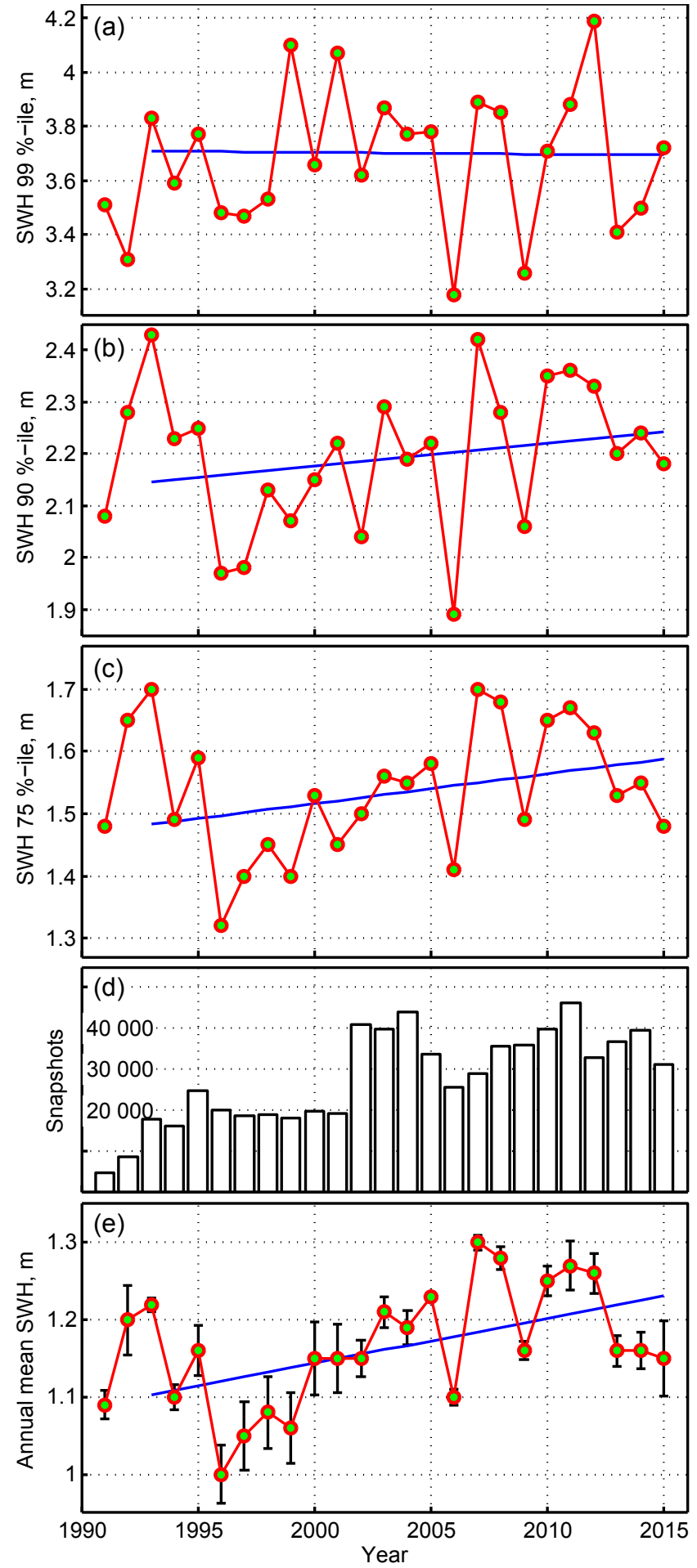

Figure 3. Wave climate derived from the satellite altimetry in terms of the annual mean SWH in the entire Baltic Sea (e); 75th percentile (c), 90th percentile (b), and 99th percentile (a) of single SWH records. The straight lines show the linear trends (regression line fitted to 1993-2015). The smaller panel (d) indicates the count of altimetry snapshots employed.
2014). Interestingly, the spatial variability of changes in these quantities is much weaker than similar variability in trends extracted from numerical simulations using modeled wind fields (Hünicke et al., 2015) and in the 90th and 99th percentiles for the North Atlantic (Bertin et al., 2013). The overall course of SWH is cyclic with a timescale of 15-20 years as suggested already by Broman et al. (2006). The higher percentiles of SWH reveal different patterns of temporal variation (Fig. 3a, b). Even though they exhibit formal, increasing trends, the changes are not statistically significant and either have a cyclic or a sawtooth-like nature with markedly different timescales: 15-20 years for the 75th percentile and, much shorter, 3-4 years for the 90th and 99th percentiles.

Simulations based on geostrophic winds indicated a complicated spatial pattern of statistically significant trends in the SWH in 1970-2007 (Soomere and Räämet, 2011). The largest increase in the SWH was identified near the Latvian coast of the Baltic Sea and a steep decrease in an area to the south of Gotland.

To assess where the changes appear locally in the Baltic Sea in our data set, we constructed maps of fitted linear trends for 1996-2015 (Fig. 4a). The presence and credibility of these changes can to some extent be evaluated based on the number of observations for each pixel used to calculate the trends (Fig. 4b). For the map of linear trends, the SWH values from single satellite altimetry snapshots were averaged for each time interval over a grid of $40 \times 40$ pixels, each pixel being $0.4 \times 0.3^{\circ}$. Only pixels that involve eight or more recordings are taken into account to avoid errors due to false averaging. The map of the number of observations per each $40 \times 40$ pixels (Fig. 4 b) shows that the number of satellite measurements is almost uniformly distributed across the Baltic Sea with systematically fewer observations next to the coast. Therefore, if trends similar to these in the western part were also present in the eastern part of the Baltic Sea, they should have been visible in the satellite altimetry data set.

Even though a certain increase in the wave activity has occurred in almost the entire sea (Fig. 4a), the changes in the SWH reveal a strong spatial pattern. The changes are minor or indistinguishable in smaller subbasins. An increase in the SWH in areas open to the North Sea is apparently connected with an increased level of storms and swells in the North Atlantic (Bertin et al., 2013). Importantly, a significant increase is observed in the western sections of the northern Baltic proper, to the southwest of Gotland, and in the southwestern part of the sea. An application of the Mann-Kendall test showed similar results (Fig. 5a). A decrease is observed in many locations near the eastern coast of the sea. Even though these changes are not directly comparable with the outcome of numerical simulations for single decades (Soomere and Räämet, 2014), they show a pattern that differs radically from the usual perception of a gradual increase in the wave activity in the eastern Baltic Sea (Hünicke et al., 2015) and also has a clear mismatch with trends established for 1970-2005 (Soomere and Räämet, 2011). 

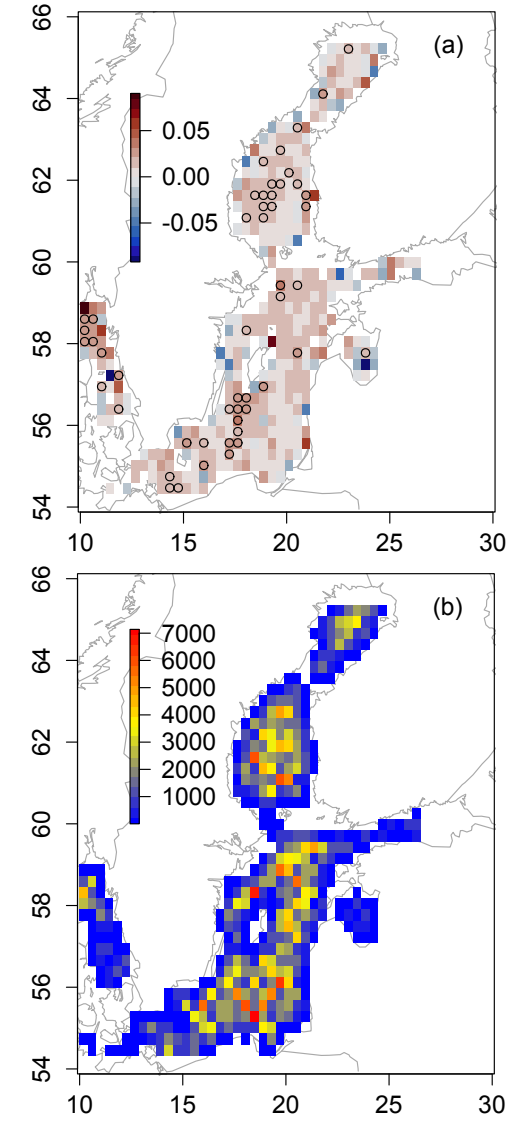

Figure 4. Spatial variability of wave climate in the Baltic Sea. (a) Slope $\left(\mathrm{m} \mathrm{yr}^{-1}\right.$; color scale) of linear trends in significant wave heights in the Baltic Sea in 1996-2015 from altimetry measurements (pixel size $0.4 \times 0.3^{\circ}$ ). Open circles indicate the pixels hosting a statistically significant (at a $>99 \%$ level) increase or decrease in the SWH. (b) Number of observations per pixel in 1996-2015 (pixel size $0.4 \times 0.3^{\circ}$ ). An increase in the pixel size compared to Fig. 2 (where the average SWH height is plotted using all available data over the whole period of observations) makes it possible to get a reasonable number of data points for each year for each particular pixel.

To rule out that the observed east-west pattern of trends can in principle be caused by an inhomogeneity of observations in time and space, a simulated dataset was created as

$H_{\mathrm{s}}=0.005 \mathrm{myr}^{-1} t+b+e r r$,

where $H_{\mathrm{S}}$ is the simulated significant wave height, $b=-10.39$ is the intercept, and err is a normally distributed random error with a standard deviation of $0.5 \mathrm{~m}$. The $H_{\mathrm{s}}$ data were selected for exactly the same locations and times as the real dataset. Then the same data analysis procedures were applied to the simulated dataset. The results are shown in Fig. $5 b$ on the same $40 \times 40$ pixel grid as in Fig. 4. Significant trends are retrieved both with linear regression and the Mann-Kendall method for the whole Baltic Sea basin, sug-
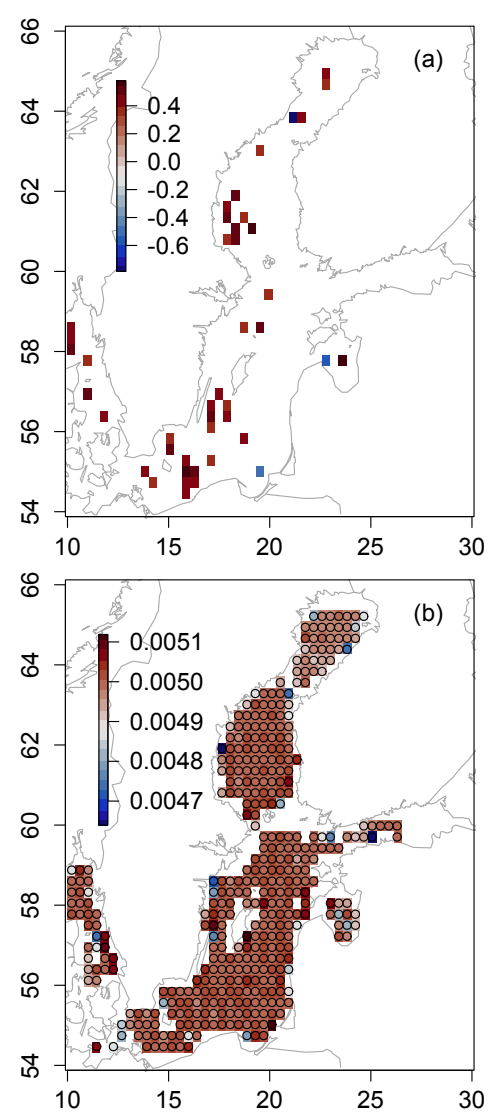

Figure 5. Spatial variability of wave climate in the Baltic Sea. (a) Mann-Kendall tau statistics of trends in SWH in the Baltic Sea in 1996-2015, winter months, from altimetry measurements (pixel size $\left.0.4 \times 0.3^{\circ}\right)$. The data are shown only for a statistically significant (at a > $95 \%$ level) increase or decrease in the SWH. (b) Trends found in synthetic data generated for the same positions and times as the studied satellite altimetry dataset in 1996-2015 (pixel size $0.4 \times 0.3^{\circ}$ ). The data were created to uniformly follow a positive trend of $0.005 \mathrm{~m} \mathrm{yr}^{-1}$. Open circles indicate statistically significant trends (at a $>99 \%$ level).

gesting that the time and space inhomogeneity in the data could not result in an observed east-west pattern of trends.

To additionally check the possible masking effect of shortterm fluctuations in the wave heights (Fig. 3), we applied the described analysis for three shorter consecutive periods: 2009-2011 (Period 1), 2011-2013 (Period 2), and 20132015 (Period 3). There was a substantial increase (up to $0.73 \mathrm{~m}$, equivalent to $4 \sigma$ (4-fold SD) variation; the false positive rate is 0.003 pixels per map) in the SWH between Period 1 and Period 2 in the northern Baltic proper (Fig. 6a). During the subsequent Periods 2 and 3, the SWH almost reverts to the level in Period 1 (Fig. 6b). The maximum decrease is $0.70 \mathrm{~m}$ (SD is $0.17 \mathrm{~m}$, which shows a difference of $4.1 \sigma$; the false positive rate at a $4 \sigma$ level is 0.01 pixels per map). 

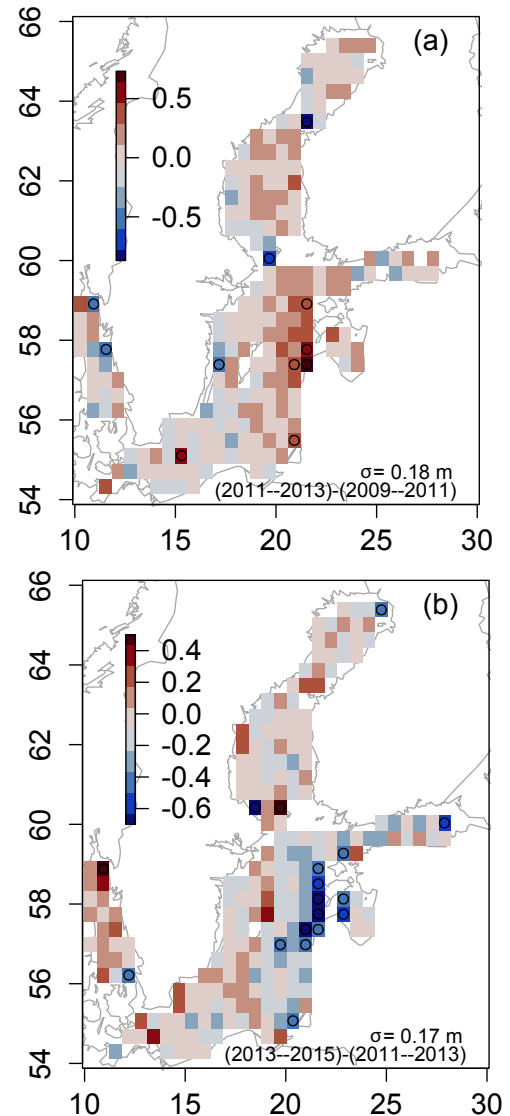

Figure 6. Local spatial variability of wave climate in the Baltic Sea. (a) Changes (m) in the average SWH from 2009-2011 to 20112013. (b) Changes (m) in the mean SWH from 2011-2013 to 20142015. Open circles indicate the pixels hosting a statistically significant (at a $>95 \%$ level) increase or decrease.

The established patterns of variations in the SWH in Fig. 4 suggest, in contrast to numerical simulations described in Hünicke et al. (2015), that a very slow increase or even a decrease in the SWH occurred along the eastern coast of the sea. As no long-term instrumental wave record exists for this region (Hünicke et al., 2015), we check this result against visually observed wave properties near the Latvian coast (Fig. 1a). Data sets with acceptable quality are available at two sites: Ventspils $\left(57.4^{\circ} \mathrm{N}, 21.53^{\circ} \mathrm{E}\right)$ and Liepāja $\left(56.47^{\circ} \mathrm{N}, 21.02^{\circ} \mathrm{E}\right)$ until 2011 (Soomere, 2013). The yearly averages of visually observed SWH show a fairly good qualitative correspondence with satellite altimetry data within $0.3^{\circ}$ from these sites (Fig. 7). The correlation coefficient between annual average SWH from the two data sets is $r=0.61$ at Liepāja, based on 10 years of coinciding data (20022011) and 444 cross matching pairs in total. At the Ventspils site (where the data quality of visual observations is lower; Soomere, 2013), the correlation is $r=0.81$ in 2009-2011, with 354 pairs. The lower correlation coefficient between the satellite altimetry data and visual observations can be the
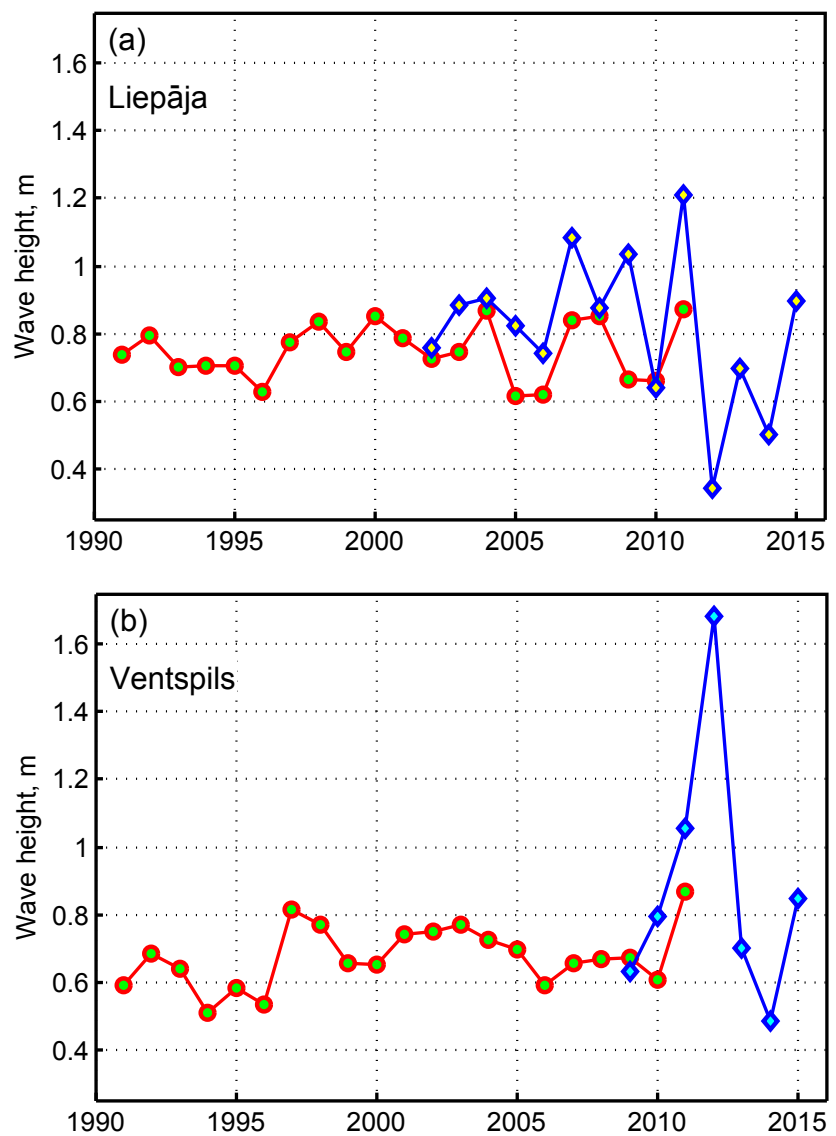

Figure 7. Comparison of average annual SWH obtained using visual observations (circles) at Liepāja (a) and Ventspils (b) and multi-mission altimetry data (diamonds, shifted down by $0.4 \mathrm{~m}$ to ease a comparison).

result of a lower number of matched pairs at this location

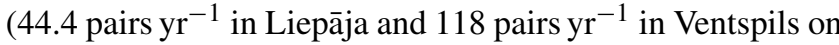
average). To test the effect of the grid cell size on the correlation coefficients, we checked the cross matches within 0.2 and $0.1^{\circ}$ from Liepāja and Ventspils observation sites but did not find a significant change in the correlation coefficients. For example, a reduction in the grid cell to $0.2^{\circ}$ almost does not affect the correlation coefficient for Liepāja $(0.60 ; 9$ years of coinciding data) and improves the formal correlation for Ventspils $(0.93 ; 3$ years of coinciding data).

\section{Discussion and conclusions}

We estimated for the first time the main properties of the wave climate of the entire Baltic Sea based on 2 decades of satellite altimetry records. Even though the resulting values of the long-term average SWH are biased towards higher waves (because records of low wave conditions are systematically ignored), the estimated average SWH reasonably matches the outcome of numerical simulations and in situ 
records. The long-term SWH over the entire sea exhibits a statistically significant increase of $0.005 \mathrm{~m} \mathrm{yr}^{-1}$. However, the presence of such a trend was not confirmed by the nonparametric Mann-Kendall test. A possible reason for the failure of this test is that the trend in question is superimposed on marked interannual variations (consistently with the overall pattern of exceptionally high interannual variability in the winter over the entire North Atlantic; Woolf et al., 2002) and a cyclic course of the overall wave activity and higher quantiles of SWH on a timescale of 15-20 years.

The commonly accepted reasons behind the possible increase in the Baltic Sea wave heights are (i) a reduction in sea ice in northern parts of the sea and (ii) an increase in the wind speed (Hünicke et al., 2015). Both these reasons should lead to a spatially inhomogeneous increase in the wave heights, first of all in the seasonally ice-covered northern part of the sea and along the eastern segments of the basin where the predominant southwesterly and north-northwesterly winds usually create the severest wave conditions. Our analysis reveals an unexpectedly strong meridional pattern of changes: the wave heights have increased in the offshore in the western part of the sea and have decreased (or exhibit no changes) along the eastern nearshore. It is, therefore, unlikely that a discernable increase in the wind speed has occurred in this region. This, among other things, means that a greater level of storms and swells (Bertin et al., 2013) may only characterize some parts of the North Atlantic. This is consistent with the conclusion that the basin-wide average geostrophic wind speed has not increased over the entire Baltic Sea (Soomere and Räämet, 2014).

The established meridional pattern of trends in the wave heights does not reflect the variations in the density of altimetry observations as shown by the synthetic trend test (Fig. 5b). Also, the short-term changes on the timescale of $\sim 3$ years are located in the Baltic proper (Fig. 6a, b), where the density of the observations is the highest. It is also not likely that the identified patterns represent systematic errors in the data set. The data used in the study were carefully cross-validated and all low-quality data excluded from the analysis. This concerns measurements in the nearshore locations $\left(<0.2^{\circ}\right.$ from the land), sea areas with ice concentration $>30 \%$, a backscatter coefficient $>13.5 \mathrm{cdb}$, and all entries with errors $>0.5 \mathrm{~m}$ in normalized SWH (see Kudryavtseva and Soomere, 2016, for more details). Implicit support for the validity of the established trends and their spatial patterns is a high correlation between visually observed wave properties and SWH derived from satellite altimetry for locations directly offshore from the coastal observation sites.

In this context, it is remarkable that no statistically significant trend in the SWH can be identified for the southeastern part of the Baltic Sea. This area evidently provides the most reliable altimetry data in the Baltic proper. This vast region of open sea has a relatively straight coastline. It hosts no islands and ice cover appears infrequently. It is natural to expect that any systematic change in the wind speed would generate an associated change in the wave heights in some part of this region. Therefore, the likely reason for the discussed pattern of changes is a rotation of the direction of moderate and strong winds. This alteration is driven by major changes in the spatial distribution of low-pressure systems over the North Atlantic and Arctic Ocean (Lehmann et al., 2011).

Even though wind direction is often considered a secondary parameter in climate studies, the impact of the rotation of wind patterns on wave fields is a generic issue (Hemer et al., 2010). This effect is comparatively strong in regional seas and large lakes with an elongated shape (Niu and Xia, 2016) where veering of the prevailing winds may lead to large changes in the fetch length. The presented results suggest that changes in wind direction may serve as the predominant driver of regional climate changes in such water bodies (Anderson et al., 2015).

Data availability. The satellite altimetry data are retrieved from the Radar Altimeter Database System (RADS) database (http://rads. tudelft.nl/rads/rads.shtml) (Scharroo et al., 2013). Annual observed wave heights in Fig. 7 are extracted from Soomere (2013).

Author contributions. N. Kudryavtseva performed the analysis of satellite altimetry data, wrote the sections that address this analysis, and prepared most of the images. T. Soomere compiled literature overview and developed the comparison of altimetry data with existing numerical simulations and visual observations. The "Results" and "Discussion" sections were written together.

Competing interests. The authors declare that they have no conflict of interest.

Acknowledgements. The research was initiated by the small grants scheme project "Effects of climate changes on biodiversity in the coastal shelves of the Baltic Sea" 2015-2016 (European Economic Area (EEA) grant no. 2/EEZLV02/14/GS/022) and supported by the institutional financing of the Estonian Ministry of Education and Research (Grant IUT33-3), the "Sebastian Checkpoints - Lot 3 Baltic" project of the call MARE/2014/09, and the ERA-NET + RUS project EXOSYSTEM (grant no. ETAG16014).

Edited by: A. Rutgersson

Reviewed by: two anonymous referees

\section{References}

Anderson, J. D., Wu, C. H., and Schwab, D. J.: Wave climatology in the Apostle Islands, Lake Superior, J. Geophys. Res., 120, 48694890, https://doi.org/10.1002/2014JC010278, 2015.

Ashton. A., Murray, A. B., and Arnault, O.: Formation of coastline features by large-scale instabilities induced by high-angle waves, Nature, 414, 296-300, https://doi.org/10.1038/35104541, 2001. 
Bertin, X., Prouteau, E., and Letetrel, C.: A significant increase in wave height in the North Atlantic Ocean over the 20th century, Glob. Planet. Change, 106, 77-83, https://doi.org/10.1016/j.gloplacha.2013.03.009, 2013.

Broman, B., Hammarklint, T., Rannat, K., Soomere, T., and Valdmann, A.: Trends and extremes of wave fields in the north-eastern part of the Baltic Proper, Oceanologia, 48, 165-184, 2006.

Cavaleri, L. and Sclavo, M.: The calibration of wind and wave model data in the Mediterranean Sea, Coast. Eng., 53, 613-627, https://doi.org/10.1016/j.coastaleng.2005.12.006, 2006.

Cieślikiewicz, W. and Paplińska-Swerpel, B.: A 44-year hindcast of wind wave fields over the Baltic Sea, Coast. Eng., 55, 894-905, https://doi.org/10.1016/j.coastaleng.2008.02.017, 2008.

EUMETSAT: Ocean and Sea Ice Satellite Application Facility, Global sea ice concentration reprocessing dataset 1978-2015, v1.2, Norwegian and Danish Meteorological Institutes, http:// osisaf.met.no/ (last access: 18 July 2017), 2015.

Francis, O. P., Panteleev, G. G., and Atkinson, D. E.: Ocean wave conditions in the Chukchi Sea from satellite and in situ observations, Geophys. Res. Lett., 38, L24610, https://doi.org/10.1029/2011GL049839, 2011.

Galanis, G., Hayes, D., Zodiatis, G., Chu, P. C., Kuo, Y.-H., and Kallos, G.: Wave height characteristics in the Mediterranean Sea by means of numerical modeling, satellite data, statistical and geometrical techniques, Mar. Geophys. Res., 33, 1-15, https://doi.org/10.1007/s11001-011-9142-0, 2012.

Gulev, S. K. and Grigorieva, V.: Variability of the winter wind waves and swell in the North Atlantic and North Pacific as revealed by the voluntary observing ship data, J. Clim., 19, 5667-5685, https://doi.org/10.1175/JCLI3936.1, 2006.

Hareef Baba Shaeb, K., Anand, A., Joshi, A. K., and Bhandari, S. M.: Comparison of near coastal significant wave height measurements from SARAL/AltiKa with wave rider buoys in the Indian Region, Mar. Geod., 38, 422-436, https://doi.org/10.1080/01490419.2015.1029655, 2015.

Hemer, M. A., Church, J. A., and Hunter, J. R.: Variability and trends in the directional wave climate of the Southern Hemisphere, Int. J. Climatol., 30, 475-491, https://doi.org/10.1002/joc.1900, 2010.

Hithin, N. K., Kumar, V. S., and Shanas, P. R.: Trends of wave height and period in the Central Arabian Sea from 1996 to 2012: A study based on satellite altimeter data, Ocean Eng., 108, 416425, https://doi.org/10.1016/j.oceaneng.2015.08.024, 2015

Høyer, J. L. and Nielsen, J. W.: Satellite significant wave height observations in coastal and shelf seas in Proc. Symp. on 15 Years of Progress in Radar Altimetry, 13-18 March 2006, Venice, Italy, edited by: Danesy, D., Paper no. 812, ESA Special Publication SP-614, Noordwijk, the Netherlands, 2006.

Hünicke, B., Zorita, E., Soomere, T., Madsen, K. S., Johansson, M., and Suursaar, Ü.: Recent change - Sea level and wind waves in The BACC II Author Team, Second Assessment of Climate Change for the Baltic Sea Basin, 155185, Regional Climate Studies, Springer, Cham, Heidelberg, https://doi.org/10.1007/978-3-319-16006-1_9, 2015.

Izaguirre, C., Méndez, F. J., Menéndez, M., and Losada, I. J.: Global extreme wave height variability based on satellite data, Geophys. Res. Lett., 38, L10607, https://doi.org/10.1029/2011GL047302, 2011.
Kendall, M. G.: Rank Correlation Methods (2nd Edn.), Charles Griffin, London, p. 196, 1955.

Kong, Y., Zhang, X., Sheng, L., and Chen, B.: Validation and application of multi-source altimeter wave data in China's offshore areas, Acta Oceanol. Sin., 35, 86-96, https://doi.org/10.1007/s13131-016-0951-5, 2016.

Kudryavtseva, N. A. and Soomere, T.: Validation of the multimission altimeter data for the Baltic Sea region, Est. J. Earth Sci., 65, 161-175, https://doi.org/10.3176/earth.2016.13, 2016.

Lehmann, A., Getzlaff, K., and Harlass, J.: Detailed assessment of climate variability in the Baltic Sea area for the period 1958 to 2009, Clim. Res., 46, 185-196, https://doi.org/10.3354/cr00876, 2011.

Leppäranta, M. and Myrberg, K.: Physical Oceanography of the Baltic Sea, Springer, Berlin, 2009.

Liu, Q., Babanin, A.V., Zieger, S., Young, I.R., Guan, C.: Wind and wave climate in the Arctic Ocean as observed by altimeters, J. Climate, 29(22), 7957-7975, https://doi.org/10.1175/JCLI-D16-0219.1, 2016.

Mann, H. B.: Non-parametric tests against trend, Econometrica, 13, 245-259, 1945.

Nikolkina, I., Soomere, T., and Räämet, A.: Multidecadal ensemble hindcast of wave fields in the Baltic Sea in The 6th IEEE/OES Baltic Symp. Measuring and Modeling of Multi-Scale Interactions in the Marine Environment, May 26-29, 2014, Tallinn Estonia, IEEE Conference Publications, https://doi.org/10.1109/BALTIC.2014.6887854, 2014.

Niu, Q. R. and Xia, M.: Wave climatology of Lake Erie based on an unstructured-grid wave model, Ocean Dynam., 66, 1271-1284, https://doi.org/10.1007/s10236-016-0982-7, 2016.

Orviku, K., Jaagus, J., Kont, A., Ratas, U., and Rivis, R.: Increasing activity of coastal processes associated with climate change in Estonia, J. Coastal Res., 19, 364-375, 2003.

Passaro, M., Fenoglio-Marc, L., and Cipollini, P.: Validation of significant wave height from improved satellite altimetry in the German Bight, IEEE T. Geosci. Remote, 53, 2146-2156, https://doi.org/10.1109/TGRS.2014.2356331, 2015.

Patra, A. and Bhaskaran, P. K.: Trends in wind-wave climate over the head Bay of Bengal region, Int. J. Climatol., 36, 4222-4240, https://doi.org/10.1002/joc.4627, 2016.

Ruest, B., Neumeier, U., Dumont, D., Bismuth, E., Senneville, S., and Caveen, J.: Recent wave climate and expected future changes in the seasonally ice-infested waters of the Gulf of St. Lawrence, Canada, Clim. Dynam., 46, 449-466, https://doi.org/10.1007/s00382-015-2592-3, 2016.

Sandwell, D. T. and McAdoo, D. C.: Marine gravity of the Southern Ocean and Antarctic margin from GEOSAT, J. Geophys. Res., 93, 10389-10396, https://doi.org/10.1007/s00382-015-2592-3, 1988.

Scharroo, R., Leuliette, E. W., Lillibridge, J. L., Byrne, D., Naeije, M. C., and Mitchum, G. T.: 2013 RADS: Consistent multimission products in Proc. Symp. on 20 Years of Progress in Radar Altimetry, 20-28 September 2012, Venice, Eur. Space Agency Spec. Publ., ESA SP-710, 2013.

Sen, P. K.: Estimates of the regression coefficient based on Kendall's tau, Journal of American Statistical Association, 63, 1379-1389, 1968.

Soomere, T.: Extending the observed Baltic Sea wave climate back to the 1940s, J. Coastal Res., 65, 1969-1974, 2013. 
Soomere, T.: Extremes and decadal variations in the Baltic Sea wave conditions in Extreme Ocean Waves, edited by: Pelinovsky, E. and Kharif, C., Springer, Cham, Heidelberg, 107-140, https://doi.org/10.1007/978-3-319-21575-4_7, 2016.

Soomere, T. and Räämet, A.: Spatial patterns of the wave climate in the Baltic Proper and the Gulf of Finland, Oceanologia, 53, 335-371, 2011.

Soomere, T. and Räämet, A.: Decadal changes in the Baltic Sea wave heights, J. Marine Syst., 129, 86-95, https://doi.org/10.1016/j.jmarsys.2013.03.009, 2014.

Soomere, T., Weisse, R., and Behrens, A.: Wave climate in the Arkona Basin, the Baltic Sea, Ocean Sci., 8, 287-300, https://doi.org/10.5194/os-8-287-2012, 2012.

Soomere, T., Bishop, S. R., Viška, M., and Räämet, A.: An abrupt change in winds that may radically affect the coasts and deep sections of the Baltic Sea, Clim. Res., 62, 163-171, https://doi.org/10.3354/cr01269, 2015.

Stopa, J. E., Ardhuin, F., and Girard-Ardhuin, F.: Wave climate in the Arctic 1992-2014: Seasonality and trends, Cryosphere, 10, 1605-1629, https://doi.org/10.5194/tc-10-1605-2016, 2016.

Suursaar, Ü.: Analysis of wave time series in the Estonian coastal sea in 2003-2014, Est. J. Earth Sci., 64, 289-304, https://doi.org/10.3176/earth.2015.35, 2015.

Tuomi, L., Kahma, K. K., and Pettersson, H.: Wave hindcast statistics in the seasonally ice-covered Baltic Sea, Boreal Environ. Res., 16, 451-472, 2011.
Tuomi, L., Pettersson, H., Fortelius, C., Tikka, K., Björkqvist, J.-V., and Kahma, K. K.: Wave modelling in archipelagos, Coast. Eng., 83, 205-220, https://doi.org/10.1016/j.coastaleng.2013.10.011, 2014.

von Storch, H. and Navarra, A. (Eds.): Analysis of Climate Variability, Springer, New York, 1995.

Wahl, T. and Plant, N. G.: Changes in erosion and flooding risk due to long-term and cyclic oceanographic trends, Geophys. Res. Lett., 42, 2943-2950, https://doi.org/10.1002/2015GL063876, 2015.

Wang, X. L. L. and Swail, V. R.: Changes of extreme wave heights in Northern Hemisphere oceans and related atmospheric circulation regimes, J. Clim., 14, 2204-2221, https://doi.org/10.1175/1520 0442(2001)014<2204:COEWHI>2.0.CO;2, 2001.

Woolf, D. K., Challenor, P. G., and Cotton, P. D.: Variability and predictability of the North Atlantic wave climate, J. Geophys. Res., 107, 3145, https://doi.org/10.1029/2001JC001124, 2002.

Young, I. R., Zieger, S., and Babanin, A. V.: Global trends in wind speed and wave height, Science, 332, 451-455, https://doi.org/10.1126/science.1197219, 2011. 